\title{
Population Growth and Environmental Impacts in Kerala
}

\author{
Ullas $\mathrm{T}^{1}$, Mahvish Anjum ${ }^{2}$ \\ ${ }^{1,2}$ (Research Scholars, Department of Geography, A.M.U., Aligarh)
}

\begin{abstract}
India has a rich tradition of environment conservation, large scale environment degradation has resulted from population pressure, industrialisation and the indiscriminate use of forest areas of fuel, power generation and irrigation purposes. The relation between population and development is a dynamic one. Present paper concerns environmental issues as related to development and population growth in Kerala. The main objective is to find out extend to which rapid population growth and industrial development is associated with the deterioration of the environment. It is the simple fact that a growing population puts pressure on both the economic and environmental systems.
\end{abstract}

Keywords: population growth, industrial development, technology, environmental deterioration.

\section{Introduction}

In 2011 world's population crossed 7 billion, after doubling in only 40 years. Much of this recent population growth took place in the less developed regions of the world. Fertility and mortality rates began to decline in the western industrial regions in the $19^{\text {th }}$ century, but only in the last decades of the $20^{\text {th }}$ century did some of the developing regions begin to realize significant decline in fertility. Given the population momentum provided by a youthful age structure, population in many parts of the World will continue to grow for many years to come.

The unprecedented rates of growth, which could have alarming effects on the environment and the life support system of the planet, have renewed the debate about the future prospects for human societies. The high rate of economic and industrial development that accompanied population growth in the $20^{\text {th }}$ century fed fear about depletion of resource and fouling of the land in biota and water in nearly all parts of the globe.

It has been an accepted fact that the quality of the natural or physical environment (air, water, climate condition, species of plants and animals) has direct significance on health and production. Environmental resources i.e. public lands forest and marine resources are common property resources, and as such there is an inherent tendency for this resource to be over exploited. Degradation of the environment in Kerala takes many forms such as deforestation, soil erosion, deterioration of water resources, pollution of air and water from industrial production. This has really a great negative impact in the development process that various strategies were conceptualised and implemented to arrest environmental degradation.

\section{Objectives}

1. To analyse the decadal population growth in India and Kerala.

2. To find out extend to which population growth is associated with deterioration of the environment. 3.

\section{Data base and methodology}

The study is mainly based on census data. For analysis simple percentage method has been used. For the discussion of study simple technique have been used. Line graph has been used for showing the population trends.

\section{Population growth and Development}

India's population according to 2011 census crossed the 1210 million mark with a decadal growth of $17.64 \%$, the corresponding figure for Kerala was 33.4 million with a growth of $4.86 \%$. The analysis of growth rate of a state starting from the decade 1951-61 tells the real story of population growth in India. It took four decade even for Kerala to reach a decadal growth of less than 10\% from a high growth rate of $26.29 \%$ during 1961-71. The growth rate in Bihar has shown an upward swing during 1991-2011 and the growth rates in Rajasthan, Uttar Pradesh, Madhya Pradesh are now at level where Kerala and Tamil Nadu were 40 years ago. 
Table. 1 Population growth India - Kerala 1951-2001

\begin{tabular}{|c|c|c|c|c|}
\hline \multirow{2}{*}{ Year } & \multicolumn{2}{|c|}{ India } & \multicolumn{2}{c|}{ Kerala } \\
\cline { 2 - 5 } & $\begin{array}{c}\text { Population (in } \\
\text { crores) }\end{array}$ & $\begin{array}{c}\text { Decadal growth } \\
(\boldsymbol{\%})\end{array}$ & $\begin{array}{c}\text { Population (in } \\
\text { crores) }\end{array}$ & $\begin{array}{c}\text { Decadal growth } \\
(\boldsymbol{\%})\end{array}$ \\
\hline 1951 & 36.10 & 13.31 & 1.35 & 22.82 \\
\hline 1961 & 43.92 & 21.64 & 1.69 & 24.76 \\
\hline 1971 & 54.82 & 24.80 & 2.13 & 26.29 \\
\hline 1981 & 68.63 & 24.66 & 2.55 & 19.24 \\
\hline 1991 & 84.34 & 23.86 & 2.91 & 14.32 \\
\hline 2001 & 102.70 & 21.34 & 3.18 & 9.42 \\
\hline 2011 & 121.01 & 17.64 & 3.34 & 4.86 \\
\hline
\end{tabular}

Source-: Census Report 2001. India Series 1 \& Series 33 Kerala Provisional Population Totals.

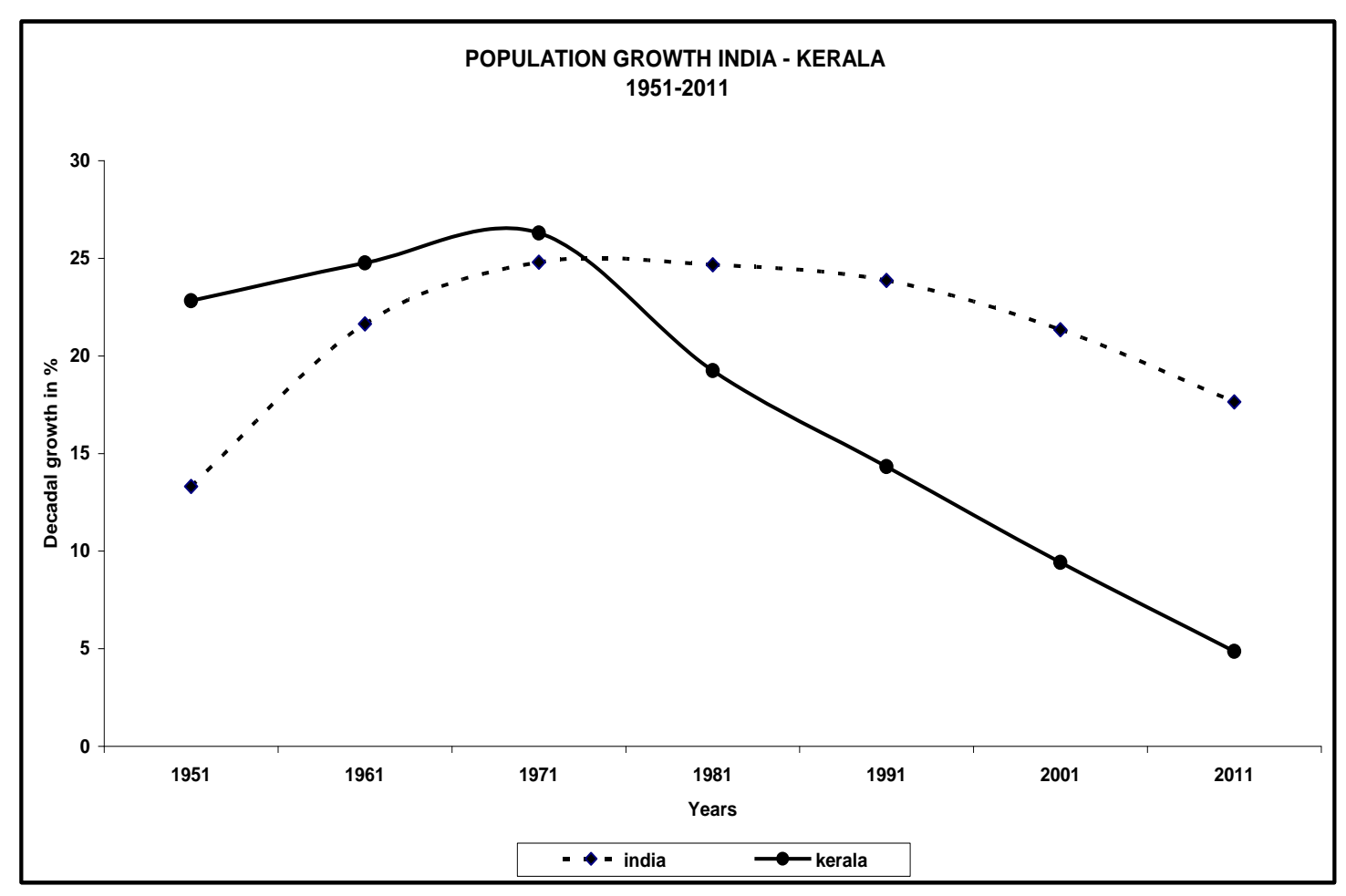

Figure 1

Kerala is home to $3.44 \%$ of India's population; at 819 persons per $\mathrm{km}^{2}$, its land is nearly three times as densely settled as the rest of India, which is at a population density of 325 persons per $\mathrm{km}^{2}$. Kerala's rate of population growth is India's lowest, and Kerala's decadal growth (4.86\% in 2011) is less than half the all-India average of 17.64\%. Whereas Kerala's population more than doubled between 1951 and 1991 by adding 15.6 million people to reach 29.1 million residents in 1991,32 million in 2011 and the population stood at less than 34 million by 2011. Kerala's coastal regions are the most densely settled, leaving the eastern hills and mountains comparatively sparsely populated. Major factor for the decline in growth rate in Kerala after 1980 was the increase in literacy among women. Increase in literacy rate creates awareness among women which control in fertility rate.

\subsection{Urban development and changes}

Urban population has been increasing all through. Growth is higher in urban areas as compared to the rural sector. The urban population of India has exceeded to the total population of all the countries of the world except China and U.S.A. The average size of an urban centre in India as per 2001 census is 100000 . Some states which could be classified as relatively more urbanised included Tamil Nadu, Gujarat, Karnataka, Punjab, West Bengal, Andhra Pradesh, Kerala and Manipur. In all these states, the proportion of population living in urban areas was more than the national average of $27.8 \%$. South India continued to be more urbanised than North in 
due factors associated with resource potential of the concerned areas and history of modern urbanisation. It is important to understand that much of the congestion in the urban places is due to the rural urban migration, which brings addition stress on resources, employment and other opportunities. The dependency in these urban areas has also increased dramatically.

The crisis faced by population growth, acute housing problems, depletion of water resources, drinking water shortages, additional creation of agricultural lands, ecological imbalances and alike including mismanagement of resources and skill lead to accumulation of problems from plan to plan.

\section{Population growth and environmental impact}

Environment refers to the some total of conditions which surround man at a given point in space and time [1]. While the environment of early man was dominated by natural factors such as vegetation, soil, climate, and other animals. Modern man has increasingly surrounded himself with an environment of his own design and construction, which is geared to the provision of food, shelter and access. Population increase is the key factor in the environmental problem and natural resources have to be considering in relation to the population which is to be provided for. With the growth of human civilization and advancement in medical facilities the world's population is growing at a very alarming rate. Because of the staggering growth of human population the environmental problem has become even worse.

Kerala is well known for having a cleaner environment than the other states of India. Environmental pollution is an emerging problem, however. The present study is focusing on the growing problems of water pollution and more generally, the policy measure that have been implemented at the national level to deal with environmental protection. The major water quality problems associated with rivers of Kerala is bacteriological pollution. The assessment of river such as Chalakkudy, Periyar, Muvattupuzha, Meenachil, Pamba and Achankovil indicate that the major quality problem is due to bacteriological pollution. There are local level quality problems faced by all rivers especially due to dumping of solid waste, bathing and discharge of effluents. With regard to ground water, water quality characteristics of well in Kerala are found to be affected by chemical and biological contaminants [2]. The open character of well and conventional maintenance habits and use of buckets and rope to draw water, kitchen wastes and pit latrines with average family land factor (5 metres) at a distance of less than 5 metre from wells are some of the factor, which are found to be contributing to the bacteriological contamination. It is observed that lack of sanitation measure in Kerala is responsible for contamination of many drinking water sources. Kerala's major industries are dumping an estimated 5 lack cubic metre of affluent containing a verity of pollutant in to the rivers of Kerala every day. Five out of ten major estuaries of the Vembanad, Ashtamudi and Veli Lake District are affected by pollution. Although no detailed study has been carried out for the entire state, sight specific analysis, specially of water quality have been conducted over the past few years. These studies indicate that the pollution problem is closely associated with land use practices. The study has found high concentration of dissolved and particulate cadmium and mercury in water sample collected from the coastal water at Cochin and Veli. Dissolved oxygen levels over biological oxygen demand levels also indicate environmental degradation. Pollution in the Vembanad estuary is attributed to industrial urban affluence from the city of Kochi and the adjoining areas. As a major an industrial centre, this region is subjected to heavy anthropogenic pressure. An estimated 3.5 billion litre of domestic sewage is produced daily in the urban areas of Kochi. Approximately $90 \%$ of this sewage is untreated and discharge in to surrounding bodies of water. Water bodies in and around Thiruvanathapuram also are affected by urban and industrial discharge. The river Periyar the longest river of the state is consider to be the life line of central Kerala, is gradually undergoing eco degradation throughout its course of the flow due to various anthropogenic stress [3].

Pollutants discharged in to the rivers and backwaters of Cochin region

\begin{tabular}{|c|c|c|c|c|c|}
\hline Sl.No & $\begin{array}{l}\text { Name of the } \\
\text { industry }\end{array}$ & Major Products & Production & $\begin{array}{l}\text { Volume of } \\
\text { effluents } \\
\text { discharged } \\
\mathrm{m}^{3} / \text { day }\end{array}$ & Major pollutants \\
\hline 1 & $\begin{array}{l}\text { Fertilizers and } \\
\text { Chemicals } \\
\text { Travancore Ltd } \\
\text { (FACT) }\end{array}$ & $\begin{array}{l}\text { Ammonium chloride, } \\
\text { Ammonium sulphate, } \\
\text { Ammoniumphosphate, } \\
\text { Ammonia, } \\
\text { Phosphoric acid. }\end{array}$ & $\begin{array}{l}75 t / \text { day } \\
600 t / d a y \\
550 t / \text { day } \\
340 t / \text { day } \\
125 t / \text { day }\end{array}$ & 71000 & $\begin{array}{l}\text { Free Ammonia, } \\
\text { Ammonical Nitrogen, } \\
\text { Fluorides, } \\
\text { Phosphates, } \\
\text { Suspended solids. }\end{array}$ \\
\hline
\end{tabular}


Population Growth and Environmental Impacts in Kerala

\begin{tabular}{|c|c|c|c|c|c|}
\hline 2 & $\begin{array}{l}\text { Travancore Cochin } \\
\text { Chemicals Ltd } \\
\text { (TCC) }\end{array}$ & $\begin{array}{l}\text { Caustic soda, } \\
\text { Liquid Chlorine+ } \\
\text { Hydrochloric Acid, } \\
\text { Sodium } \\
\text { Hydrosulphate, } \\
\text { Sodium Sulphide }\end{array}$ & $\begin{array}{l}2775 \mathrm{t} / \mathrm{mth} \\
2487 \mathrm{t} / \mathrm{mth} \\
10 \mathrm{t} / \mathrm{mth} \\
54 \mathrm{t} / \mathrm{mth}\end{array}$ & 10200 & $\begin{array}{l}\text { Mercury, } \\
\text { Free chlorine, } \\
\text { Suspended solids. }\end{array}$ \\
\hline 3 & $\begin{array}{l}\text { Cominco Binani } \\
\text { Zinc Ltd (CBZ) }\end{array}$ & $\begin{array}{l}\text { Zinc Slabs, } \\
\text { Cadmium. }\end{array}$ & $\begin{array}{l}7000 \mathrm{t} / \mathrm{yr} \\
36 \mathrm{t} / \mathrm{yr}\end{array}$ & 2315 & $\begin{array}{l}\text { Zinc, } \\
\text { Lead. }\end{array}$ \\
\hline 4 & $\begin{array}{l}\text { United Catalysts } \\
\text { India Ltd. (UCIL) }\end{array}$ & $\begin{array}{l}\text { Metallic Catalysts for } \\
\text { fertilizers and } \\
\text { petrochemical } \\
\text { industries }\end{array}$ & & 2800 & Hexavalent Chromium \\
\hline 5 & $\begin{array}{l}\text { Periyar Chemicals } \\
\text { Ltd. (PCL) }\end{array}$ & $\begin{array}{l}\text { Formic Acid, } \\
\text { Sodium Formate. }\end{array}$ & $\begin{array}{l}85 \mathrm{t} / \mathrm{mth} \\
165 \mathrm{t} / \mathrm{mth}\end{array}$ & 120 & $\begin{array}{l}\text { Insecticides (DDT \& } \\
\text { BHC) }\end{array}$ \\
\hline 6 & $\begin{array}{l}\text { Hindustan } \\
\text { Insecticides Ltd } \\
(\mathrm{HIL})\end{array}$ & $\begin{array}{l}\text { DDT(Tech), } \\
\text { DDT (50\%), } \\
\text { BHC(Tech), } \\
\text { BHC (50\%), } \\
\text { Hydrochloric Acid, } \\
\text { Sulphuric Acid. }\end{array}$ & $\begin{array}{l}1334 \mathrm{t} / \mathrm{yr} \\
2688 \mathrm{t} / \mathrm{yr} \\
3000 \mathrm{t} / \mathrm{yr} \\
3000 \mathrm{t} / \mathrm{yr} \\
1689 \mathrm{t} / \mathrm{yr} \\
1278 \mathrm{t} / \mathrm{yr}\end{array}$ & 2245 & \\
\hline 7 & $\begin{array}{l}\text { Thottakattu } \\
\text { Distilleries }\end{array}$ & Rectified sprit & $\begin{array}{l}5500 \\
\mathrm{~L} / \mathrm{mth}\end{array}$ & $\begin{array}{l}65 \\
\text { (discharged } \\
\text { in to well) }\end{array}$ & Sulphides \\
\hline 8 & $\begin{array}{l}\text { Travancore } \\
\text { Chemicals } \\
\text { Manufacturing Co. } \\
\text { Ltd.(TCM) }\end{array}$ & $\begin{array}{l}\text { Copper Sulphate, } \\
\text { Copper Oxychloride, } \\
\text { Sodium Aluminate, } \\
\text { Sulphate of Alumina, } \\
\text { Allumino Ferric, } \\
\text { Potassium Chlorate. }\end{array}$ & $\begin{array}{l}3000 \mathrm{t} / \mathrm{yr} \\
900 \mathrm{t} / \mathrm{yr} \\
1020 \mathrm{t} / \mathrm{yr} \\
1200 \mathrm{t} / \mathrm{yr} \\
1800 \mathrm{t} / \mathrm{yr} \\
1200 \mathrm{t} / \mathrm{yr}\end{array}$ & 655 & Copper \\
\hline 9 & Premier Tyers Ltd. & $\begin{array}{l}\text { Automobile Tyres, } \\
\text { Automobile Tubes, } \\
\text { Automobile Flaps. }\end{array}$ & $\begin{array}{l}1500 / \text { day } \\
1200 / \text { day } \\
700 / \text { day }\end{array}$ & $\begin{array}{l}600 \\
\text { (discharged } \\
\text { in to land } \\
\text { surface) }\end{array}$ & \\
\hline 10 & $\begin{array}{l}\text { Indian Aluminium } \\
\text { Co. Ltd. } \\
\text { (INDALCO) }\end{array}$ & $\begin{array}{l}\text { Primary Aluminium } \\
\text { Ingots, } \\
\text { Aluminium propersy } \\
\text { Redraw Rods, } \\
\text { Aluminium } \\
\text { Extrusions. }\end{array}$ & $\begin{array}{l}15850 \\
\text { t/mth } \\
10000 \\
\text { t/mth } \\
3760 \mathrm{t} / \mathrm{mth}\end{array}$ & 13700 & Heavy Metals \\
\hline
\end{tabular}

Source: State of Environment Report, Kerala 2005

Back water and rural estuary in Kerala experience varying degree of pollution. Apart from urbanisation and industrialisation in the low land and coastal plain, the common practice of coconut ratting is the process through which coconut husk immersed in brackish water before fibre is extracted from the husk.

Finally because fresh water environment is optimal for growing rice, rice is cropped three times annually and it requires heavy use of fertilizers. Residual nitrates have contributed to water quality problems. Pollution attributed to fertilizers and pesticides residues is reported in the Alappuzha and the Kottayam areas. And the algae blooms observed in rice fields are possibly associated with an increase in nitrate level.

Population pressure, unemployment and state policies in Kerala have encouraged large scale internal migration which has resulted in rapid deforestation of this region to which people moved. Large-scale deforestation in the Western Ghats and introduction of plantation crops in highlands replacing the natural vegetation reduced the storage capacity of soil and resulted in surface soil erosion in watersheds and sedimentation in rivers. The consequences of deforestation include frequent flash floods, landslides, soil erosion and silting of reservoirs, all capable of causing serious ecological and environmental problem. Population growth has also has lead to conversion of rice land to among other things, Sand quarrying in rivers and watersheds are killing the rivers. Such activities lead to bank erosion, lowering of water table and create several environmental problems [4]. 
Clay mining contributes to declining in the ground water recharging capacity and in the water retention capacity of the soil and also adversely affecting paddy cultivation.

Urbanization in Kerala differs from that in the rest of India, because the state is dominated by small, well distributed urban centre rather than enlarge mega city. More over Kerala displays a unique rural urban continuum [5]. The local populace prefer to live in single family housing and the significantly more land is required to house the population in other part of the country. Lack of employment opportunity for a large number of educated hopefuls and the shortage of arable land have provided strong incentives for inter regional interstate and international migration [6]. Thus, the state economy has become some what depend on remittances. The use of remittances for non productive activity especially acquisition of consumer items manufacture outside the state has earned Kerala a reputation as a consumer state. In the absence of major investments in productive sector it is likely that the state will remain a net consumer in the future.

\section{Conclusion and suggestions}

In the demographic perspective, we can say that population in many countries including India will continue to grow up to later half of the next century irrespective of the fertility trends, although the statistics shows that it is already exhibiting a downward trend. In the particular context of Kerala's richness in natural resource is endangered by the continuing rapid population growth which is exerting pressure to this wealth. This situation also brought about the wide spread prevalence of poverty which only widen the gap for the country to attain its desired national development. Environmental concerns have assumed significance in the recent years. Commensurate with industrial expansion, a strong regulatory mechanism is required to ensure minimum environmental standards. It has already being a widely known fact that rapid population growth has great implication to any countries progress. And it is therefore imperative at this point of time to determine the answers and solutions to the problem that we are now confronting.

There are some measures for controlling the environmental problems, these are as follows.

- Control the practice of plantation crops in highland replacing the natural vegetation.

- Make efficient steps to stop sand quarrying and agricultural practice in rivers banks and watersheds.

- Introduce efficient water treatment system in industries and city municipalities to control the inflow of untreated domestic, industrial waste and agricultural runoff.

- Implement strict laws on KLU (Kerala Land Utilization) to control land filling (ponds, farmlands, wetlands and other water bodies)

- Conducting adequate testing and regular monitoring of drinking water quality.

- A comprehensive approach towards water resource management is needed to address the myriad water quality problems that exist today from non-point and point source as well as from habitat degradation.

- Not implementing any timber management in riparian areas without proof that these activities actually increase coarse woody debris above benefits outweighs the risks (sedimentation, oil and fuel runoff, etc).

- Eliminating commercial logging and unrestrained recreation in municipal watersheds.

- Recycling and proper disposal of household chemicals and wastes and proper maintenance of on site septic systems to reduce nutrient loading.

\footnotetext{
References:

[1] Jat B.C and Sujatha Mathur (2007), Environmental Studies, Agarwal Publishing House, Jaipur.

[2] State of Environment Report, Kerala 2005

[3] www.status Report on Periyar - krpcds.org/report/Joseph\%20M.L.pdf

[4] http://www.meanausa.org/html/manoramaReport/report1.pdf

[5] Kerala Economic Review 2010- State Planning Commission, Thiruvanathapuram, Chapter 3, pp - 32.

[6] Rajan, S.I and et.al (2001), Demographic transition and economic development in Kerala- the role of emigration. Project report submitted as a part of MIR study to the SANEI.
} 